JEBI Vol. 1, No. 2, Jul-Des, Hal. 41-49

Copyrigt @ 2016 Fakultas Ekonomi dan Bisnis UTS

Jurnal Ekonomi dan Bisnis Indonesia

\title{
DAMPAK OTONOMI DAERAH: REALISASI PERENCANAAN KEUANGAN KABUPATEN SUMBAWA DENGAN TERBENTUKNYA KABUPATEN SUMBAWA BARAT
}

\author{
The Impact of Regional Autonomy: Realization of Government Financial Planning in Sumbawa \\ Regency After the Separation with West Sumbawa Regency
}

\author{
Sri Andriani ${ }^{1}$ \\ ${ }^{1}$ Program Studi Manajemen Fakultas Ekonomi dan Bisnis Universitas Teknologi Sumbawa \\ *) e-mail: sri.andriani@uts-sumbawa.ac.id \\ Tanggal diterima: 15 September 2016
}

\begin{abstract}
Regional autonomy in Indonesia encouraged the local governments to divide their region in to some local governments in order to increase people prosperity. One of the newly built region is West Sumbawa Regency (KSB) which was a part of Sumbawa Regency territory before the separation process. This condition affects the realization of financial planning in Sumbawa Regency as the core region. Declining in PAD compare to total income of Sumbawa local government is one of the evidence that the existence of KSB affects the financial realization of Sumbawa's government. The aim of this research is to know the difference level of financial planning realization in Sumbawa Regency before and after the existence of KSB. This research using t-test analysis to compare the condition between before and after the existence of KSB. The result of this research shows that there is no significant differences in financial planning realization which measured by effectiveness, efficiency, decentralization degree, dependency ratio, and the degree of independence before and after the existence of $K S B$.
\end{abstract}

Keywords: Regional autonomy, Financial planning, Effectiveness ratio, Efficiency ratio, Regional finance

\section{ABSTRAK}

Otonomi Daerah mendorong terjadinya pemekaran maupun penggabungan daerah menjadi suatu daerah baru, salah satunya terbentuknya Kabupaten Sumbawa Barat (KSB) yang dulunya merupakan bagian dari Kabupaten Sumbawa. Hal ini mempengaruhi realisasi perencanaan keuangan Kabupaten Sumbawa selaku daerah induk, terbukti dengan menurunnya kontribusi PAD terhadap total pendapatan daerah. Penelitian ini bertujuan untuk mengetahui tingkat signifikansi perbedaan realisasi perencanaan keuangan Kabupaten Sumbawa sebelum dan sesudah terbentuknya KSB. Penelitian ini menggunakan analisis uji-t untuk membandingkan kondisi realisasi perencanaan keuangan Kabupaten Sumbawa sebelum dan setelah terbentuknya KSB. Hasil penelitian terhadap variabel kinerja keuangan daerah menunjukkan bahwa: Tidak terdapat perbedaan yang signifikan dalam realisasi perencanaan keuangan Kabupaten Sumbawa yang diukur dengan Tingkat Efektivitas, Tingkat Efisiensi, Derajat Desentralisasi, Tingkat Ketergantungan, dan Tingkat Kemandirian Kabupaten Sumbawa sebelum dan sesudah terbentuknya KSB.

Kata Kunci : Otonomi daerah, Perencanaan keuangan, Rasio efektivitas, Rasio efisiensi, Keuangan daerah

Pembangunan daerah sebagai bagian yang integral dari pembangunan nasional merupakan usaha yang ditujukan dalam upaya peningkatan sumber daya manusia, peningkatan taraf hidup masyarakat, penciptaan lapangan kerja, serta pemerataan pembangunan antar wilayah. Dalam pelaksanaannya, daerah akan mengacu pada karakteristik dan kepribadian daerah atau bangsa secara serasi maupun terpadu antara pembangunan sektoral dan pembangunan regional menuju kemandirian daerah yang diwujudkan dengan terselenggaranya otonomi daerah. Harapan dilaksanakannya otonomi daerah atau disentralisasi adalah pemerintah daerah akan lebih fleksibel dalam mengatur strategi pembangunannya, karena dengan otonomi daerah pemerintah akan lebih dekat dengan masyarakatnya, sehingga makin banyak keinginan masyarakat dapat dipenuhi oleh pemerintah. Dengan otonomi daerah, anggaran daerah menjadi pintu penting yang paling mungkin setiap daerah mendinamisir kegiatan pembangunan melalui alokasi yang tepat dalam rangka membuat strategi untuk menciptakan kebijakan yang lebih tepat sesuai situasi masing-masing daerah (Yustika, 2007 dalam Batafor, 2011). Penyelenggaraan otonomi daerah harus selalu berorientasi pada peningkatan kesejahteraan masyarakat dengan selalu memperhatikan kepentingan dan aspirasi yang tumbuh 
dalam masyarakat. Untuk itu, otonomi daerah diharapkan dapat menciptakan efisiensi dan efektivitas pengelolaan sumber daya daerah, meningkatkan kualitas pelayanan umum dan kesejahteraan masyarakat dan menciptakan ruang bagi masyarakat untuk ikut berpartisipasi dalam proses pembangunan. (Mardiasmo, 2002 dalam Batafor, 2011). Penegasan semangat otonomi daerah semakin nyata dengan pemberlakuan Undang-Undang (UU) No. 22 tahun 1999 yang diperbaharui menjadi UU No. 33 tahun 2004 tentang Pemerintah Daerah dan UU No. 25 tahun 1999 yang diperbaharui menjadi UU No. 32 tahun 2004 tentang Perimbangan Keuangan antara Pemerintah Pusat dan Pemerintah Daerah.

Untuk melihat kemampuan suatu daerah, salah satunya dapat diukur melalui realisasi perencanaan keuangan. Perencanaan dalam keuangan daerah pada umumnya merupakan bagian program atau kegiatan dari pengelolaan keuangan daerah yang akan dilaksanakan berikut target kinerja yang akan dicapai. Tolak ukur untuk kinerja adalah ukuran keberhasilan yang dicapai pada setiap unit kerja mampu melaksanakan tupoksinya. (Amri, 2007)

Salah satu indikator penilainya adalah dengan melihat jumlah realisasi pendapatan asli daerah dan pendapatan transfer. Berikut Pendapatan Asli Daerah dan Pendapatan Transfer Kabupaten Sumbawa yang terlampir dalam APBD Kabupaten Sumbawa

Tabel 1. Pendapatan Asli Daerah dan Pendapatan Transfer Kabupaten Sumbawa Sebelum dan Sesudah Terbentuknya KSB (dalam juta)

\begin{tabular}{rrrrrr}
\hline No & Tahun & \multicolumn{1}{c}{$\begin{array}{c}\text { PAD } \\
\text { (Rp) }\end{array}$} & \multicolumn{1}{c}{$\begin{array}{c}\text { Growth } \\
(\%)\end{array}$} & $\begin{array}{c}\text { Pendapatan } \\
\text { Transfer } \\
\text { (Rp) }\end{array}$ & \multicolumn{1}{c}{$\begin{array}{c}\text { Growth } \\
(\%)\end{array}$} \\
\hline 1 & 2000 & 4.523 & - & 79.646 & - \\
2 & 2001 & 10.358 & 128,99 & 244.338 & 206,78 \\
3 & 2002 & 17.217 & 66,22 & 239.447 & $-2,00$ \\
4 & 2003 & 20.084 & 16,65 & 264.774 & 10,58 \\
5 & 2004 & 18.845 & $-6,17$ & 292.156 & 10,34 \\
6 & 2005 & 15.809 & $-16,11$ & 228.711 & $-21,72$ \\
7 & 2006 & 19.284 & 21,98 & 343.047 & 49,99 \\
8 & 2007 & 20.438 & 5,99 & 453.026 & 32,06 \\
9 & 2008 & 25.912 & 26,78 & 541.820 & 19,60 \\
10 & 2009 & 28.499 & 9,98 & 556.957 & 2,79 \\
11 & 2010 & 35.809 & 25,65 & 624.619 & 12,15 \\
\hline \multicolumn{7}{c}{ Total } & 216.783 & 279,96 & 3.868 .546 & 320,57 \\
\multicolumn{7}{c}{ Rata-rata } & 19.707 & 28,00 & 351.686 & 32,06 \\
\hline
\end{tabular}

Sumber : Bagian Keuangan Kabupaten Sumbawa

Dari tabel 1 di atas terlihat bahwa rata-rata pertumbuhan pendapatan Kabupaten Sumbawa selama tahun 2000-2010 sebesar 28,00\%, lebih kecil jika dibandingkan dengan pertumbuhan pendapatan transfer yang mencapai $32,06 \%$. Ini mengindikasikan seiring meningkatnya Pendapatan Asli Daerah (PAD) diikuti pula dengan meningkatnya pendapatan transfer berarti secara umum tingkat ketergantungan kepada pemerintah pusat masih cukup tinggi. PAD Kabupaten Sumbawa sebelum pembentukan KSB (tahun 2000-2004) mengalami peningkatan pertumbuhan tertinggi pada tahun 2001 sebesar 128,99\%, diikuti peningkatan pertumbuhan pendapatan transfer sebesar $206,78 \%$. Artinya awal berlakunya otonomi daerah, pemerintah pusat memberikan kontribusi yang cukup besar. Pertumbuhan terendah terjadi pada tahun 2004 sebesar $(6,17 \%)$ dengan pertumbuhan pendapatan transfer sebesar $10,34 \%$, dengan persentase tersebut, berarti peran pemerintah pusat sudah mulai menurun.

Sedangkan setelah terbentuknya KSB (tahun 2005-2010), PAD Kabupaten Sumbawa terus mengalami peningkatan. Peningkatan tertinggi terjadi pada tahun 2008 sebesar 26,78\% dengan pendapatan transfer yang juga meningkat sebesar 19,60\%. Peningkatan PAD terendah terjadi pada tahun 2005 sebesar $(16,11 \%)$ dengan diikuti pula penurunan pertumbuhan pendapatan transfer sebesar $(21,72 \%)$, penurunan ini menandakan resminya KSB memiliki laporan APBD yang sudah terpisah dengan Kabupaten Sumbawa. Ini tentunya menggambarkan bahwa sesudah terbentuknya KSB, PAD memang mengalami peningkatan tetapi meningkat pula pendapatan transfer dari pemerintah pusat artinya peran pemerintah pusat terhadap Kabupaten Sumbawa terus meningkat setelah terbentuknya KSB. Padahal seharusnya dengan terjadinya pemekaran maka akan mengurangi jumlah penduduk Kabupaten Sumbawa sehingga penggunaan pendapatan khususnya PAD hanya akan terpusat pada daerah yang dimiliki saat ini.

Dengan hanya menganalisis pendapatan tentunya tidak akan terlalu memperlihatkan kondisi sesungguhnya dari Kabupaten Sumbawa. Maka untuk melengkapi analisis data di atas, berikut diuraikan anggaran dan realisasi pendapatan, belanja, dan surplus/defisit Kabupaten Sumbawa.

Tabel 2. Persentase Pendapatan dan Belanja Daerah Kabupaten Sumbawa Sebelum dan Sesudah Terbentuknya KSB

\begin{tabular}{|c|c|c|c|c|}
\hline \multirow[t]{2}{*}{ No } & \multirow{2}{*}{ Tahun } & $\begin{array}{c}\text { Pendapatan } \\
\text { Daerah }\end{array}$ & $\begin{array}{l}\text { Belanja } \\
\text { Daerah } \\
\end{array}$ & $\begin{array}{c}\text { Surplus } \\
\text { (Defisit) }\end{array}$ \\
\hline & & $\%$ & $\%$ & $\%$ \\
\hline 1 & 2000 & 102,27 & 97,6 & 123,94 \\
\hline 2 & 2001 & 107,36 & 96,31 & 121,93 \\
\hline 3 & 2002 & 108,03 & 92,83 & 30,51 \\
\hline 4 & 2003 & 99,51 & 98,18 & 66,55 \\
\hline 5 & 2004 & 102,25 & 94,38 & $-604,97$ \\
\hline 6 & 2005 & 98,33 & 89,37 & 100 \\
\hline 7 & 2006 & 99,92 & 91,66 & 100 \\
\hline 8 & 2007 & 103,16 & 90,19 & 100 \\
\hline 9 & 2008 & 101,72 & 86,73 & 100 \\
\hline 10 & 2009 & 102,49 & 92,05 & 100 \\
\hline
\end{tabular}




\begin{tabular}{lrrrr}
11 & 2010 & 99,57 & 92,26 & 100 \\
\hline Total & $1.124,61$ & $1.021,56$ & 337,96 \\
Rata-rata \% & 102,24 & 92,87 & 30,72 \\
\hline Sumber: & $\begin{array}{c}\text { Bagian } \\
\text { Sumbawa }\end{array}$ & Keuangan & Pemerintah & Daerah Kabupaten \\
\multicolumn{2}{l}{ Sumbar Ka }
\end{tabular}

Pendapatan dan belanja daerah merupakan bagian yang tidak terpisahkan, karena prinsip otonomi daerah mengamanahkan untuk meningkatkan kesejahteraan masyarakat oleh pemerintah daerah yang dapat diukur dari kemampuan keuangan daerah dalam meningkatkan pendapatan dan belanja daerah. Terjadinya peningkatan pendapatan akan dapat memberikan dampak terhadap tingkat belanja daerah dalam meningkatkan kesejahteraan masyarakat apabila pengelolaan keuangan daerah dilakukan secara efektif dan efisien sehingga akan dapat dilihat capaian dari anggaran yang telah ditetapkan dalam rancangan APBD, apakah terjadi surplus atau defisit. Sebagai gambaran dapat dilihat pencapaian realisai anggaran pendapatan dan belanja daerah dalam melakukan efisiensi dan efektivitas anggaran.

Dengan melihat perkembangan pendapatan daerah selama 11 (sebelas) tahun terakhir anggaran tahun 2000-2010, dapat dikatakan bahwa kinerja anggaran pendapatan dan belanja daerah sebelum maupun sesudah terbentuknya KSB cukup baik. Kinerja pendapatan Kabupaten Sumbawa cukup baik yang ditandai dengan capaian pendapatan secara umum melampaui target anggaran, belanja juga menunjukkan kinerja yang baik yang ditandai dengan realisasi belanja yang di bawah jumlah yang dianggarakan. Hal ini tentunya sesuai dengan yang diharapkan karena dengan pergerakan yang searah berarti program yang direncanakan diimplementasikan dengan tepat. Meningkatnya belanja daerah dipengaruhi oleh pertumbuhan penduduk yang menghendaki adanya pelayanan pemerintah, sehingga orientasi penggunaan anggaran bergerak untuk kepentingan publik.

Pada tabel 2 tersebut, diperoleh keterangan bahwa rata-rata capaian pendapatan dan belanja daerah Kabupaten Sumbawa masing-masing sebesar $102,24 \%$ dan $92,87 \%$, artinya secara umum kinerja pendapatan dan belanja Kabupaten Sumbawa cukup baik. Sebelum terbentuknya KSB, pada tahun 2003, Kabupaten Sumbawa belum mampu melampaui target yang telah dianggarkan. Pada awalnya dianggarkan akan surplus malah defisit dengan selisih sebesar $66,55 \%$. Sebaliknya pada tahun 2004, awalnya dianggarkan defisit malah terjadi surplus dengan selisih sebesar (-604,97\%). Setelah terbentuknya KSB, secara berturut-turut pada tahun 2005, 2006 dan 2010 (99,33\%, 98,92\% dan 99,57\%), Kabupaten Sumbawa menunjukkan kinerja yang kurang baik karena pada tahun tersebut capaian pendapatan belum mampu melampaui target yang telah dianggarkan namun belanja daerah mampu ditekan tanpa melampaui target yang telah dianggarkan. Sebaliknya dua tahun berturut-turut Kabupaten Sumbawa mengalami defisit yaitu pada tahun 2009 dan 2010 karena sampai saat ini Kabupaten Sumbawa masih memusatkan pada pembangunan daerah.

Sistem anggaran tradisional yang bersifat incrementalism dan line-item dengan pendekatan anggaran berimbang (balanced budget), sebagaimana diimplementasikan selama era Orde Baru, menilai kinerja anggaran berdasarkan habis tidaknya anggaran. Jika unit kerja berhasil menghabiskan anggaran maka unit kerja tersebut akan dinilai berhasil, sebaliknya jika tidak dapat menyerap seluruh anggaran akan dinilai kurang berhasil. Namun dengan sistem penganggaran kinerja (perfomnace budgeting), kinerja anggaran tidak lagi didasarkan habis tidaknya anggaran, tetapi diukur dari tercapai tidaknya target kinerja dengan anggaran yang disediakan. Dalam sistem anggaran kinerja, sisi anggaran tidak berarti buruk dan dan berakibat dipotongnya anggaran periode berikutnya. Bahkan apabila terdapat sisa anggaran maka sisa tersebut dapat digunakan untuk anggaran tahun berikutnya sehingga tidak akan hangus. (Mahmudi, 2007).

Berkaitan dengan hal itu, analisis terhadap realisasi perencanaan keuangan pemerintah Kabupaten Sumbawa merupakan informasi yang penting terutama untuk membuat kebijakan dalam pengelolaan keuangan daerah dan menilai apakah pemerintah kabupaten berhasil mengelola keuangannya dengan baik, serta memberikan dampak yang positif terhadap kesejahteraan masyarakat. Analisis kinerja keuangan pada APBD dilakukan dengan cara membandingkan hasil yang dicapai dari satu periode dengan periode sebelumnya, sehingga dapat diketahui bagaimana kecenderungan yang terjadi. Selain itu dapat pula dilakukan dengan cara menganalisis rasio-rasio keuangan. Rendahnya kapasitas dan kemampuan pengelolaan keuangan daerah akan sering menimbulkan siklus efek negatif, yaitu rendahnya tingkat pelayanan bagi masyarakat dan tidak mampu meningkatkan kesejahteraan masyarakat.

Penggunaan analisis rasio keuangan sebagai alat analisis kinerja keuangan secara luas telah diterapkan pada lembaga perusahaan yang bersifat komersial, sedangkan pada lembaga publik khususnya pemerintah kabupaten masih sangat terbatas sehingga secara teoritis belum ada kesepakatan yang bulat mengenai nama dan kaidah pengukurannya. Dalam rangka pengelolaan keuangan daerah yang transparan, jujur, demokratis, efektif, efisien, dan akuntabel, maka analisis rasio keuangan terhadap pendapatan belanja daerah perlu dilaksanakan (Mardiasmo, 2002: 169 dalam Betafor, 2011).

Selaras dengan Mardiasmo, Menurut Widodo dalam Halim (2004:283) dalam rangka pengelolaan keuangan daerah yang transparan, jujur, demokratis, efektif, efisien, dan akuntabel, analisis rasio keuangan terhadap pendapatan belanja daerah perlu dilaksanakan meskipun terdapat perbedaan kaidah pengakuntansiannya dengan laporan keuangan yang dimiliki perusahaan swasta.

Berdasarkan uraian di atas, maka penulis memandang perlu untuk menganalisis realisasi perencanaan keuangan pemerintah kabupaten selama ini sehingga dapat menjadi suatu informasi yang penting terutama untuk membuat kebijakan dalam pengelolaan keuangan daerah dan menilai apakah pemerintah Kabupaten Sumbawa mampu dan telah berhasil mengelola keuangannya dengan baik sesudah terbentuknya KSB atau malah sebaliknya, pembentukan KSB menyebabkan rendahnya tingkat pengelolaan keuangan Kabupaten Sumbawa. 
Adapun tujuan dari penelitian ini adalah Untuk mengetahui signifikansi perbedaan realisasi perencanaan keuangan Kabupaten Sumbawa yang diukur atas dasar Efektivitas, Efisiensi, Derajat Desentralisasi, Tingkat Ketergantungan, dan Tingkat Kemandirian sebelum dan sesudah terbentuknya KSB.

\section{Metode Penelitian}

Jenis penelitian yang digunakan dalam penelitian ini adalah penelitian komparatif yaitu suatu penelitian yang bersifat membandingkan (Sugiyono, 2004). Metode ini digunakan karena dalam penelitian ini memberikan gambaran mengenai perbandingan realisasi perencanaan keuangan yang diukur atas dasar Efektivitas, Efisiensi, Derajat Desentralisasi, Tingkat Ketergantungan, dan Tingkat Kemandirian Kabupaten Sumbawa sebelum dan sesudah terbentuknya KSB. Penelitian ini dilakukan di Kabupaten Sumbawa Provinsi NTB.

Penelitian ini dilakukan di pemerintah Kabupaten Sumbawa melalui wawancara dengan pihak-pihak terkait seperti Kepala Bagian Keuangan, data-data yang dibutuhkan khususnya Laporan Realisasi Anggaran. Penelitian ini dilakukan di Kabupaten Sumbawa dengan alasan sebagai berikut :

a. Kabupaten Sumbawa merupakan kabupaten yang pada 18 Desember 2003 mengalami pemekaran pada beberapa kecamatannya yaitu kecamatan Taliwang dan sekitarnya menjadi Kabupaten Sumbawa Barat.

b. Kabupaten Sumbawa Barat memiliki prospek ekonomi yang besar karena memiliki potensi daerah yang tinggi terbukti dari tingginya pertumbuhan PADnya sehingga ketika terjadi pemekaran diduga akan menyebabkan berpengaruhnya Pendapatan Kabupaten Sumbawa.

Teknik pengumpulan data yang digunakan adalah dokumentasi wawancara. Dokumentasi adalah dengan melakukan pencatatan atas dokumen yang dipublikasikan oleh Pemda Kabupaten Sumbawa dan wawancara adalah mengumpulkan informasi melalui pihak terkait (Kepala Bagian Keuangan Pemda Sumbawa) tentang kondisi keuangan Kabupaten Sumbawa. Data yang dikumpulkan dengan teknik tersebut adalah data-data perkembangan Laporan Realisasi Anggaran tahun 2000 sampai dengan tahun 2010 .

Jenis data yang digunakan dalam penelitian ini adalah : (1) Data Kuantitatif, yaitu data yang berupa angka-angka dan dapat dianalisa secara sistematis seperti jumlah atau satuan tertentu dalam penelitian ini berupa Laporan Realisasi Anggaran; (2) Data Kualitatif, yaitu data yang tidak berupa angka-angka namun berupa keterangan-keterangan seperti gambaran umum Pemerintah Kabupaten Sumbawa.

Data yang digunakan dalam penelitian ini adalah data sekunder yaitu data penelitian yang diperoleh secara tidak langsung melalui media perantara (dihasilkan pihak lain) dan data sekunder pada umumnya berbentuk catatan atau laporan data dokumentasi oleh lembaga tertentu yang dipublikasikan (Ruslan, 2003 :138). Dalam penelitian ini berupa data Laporan Realisasi Anggaran tahun 2000-2010.

Variabel yang akan dianalisis adalah variabel realisasi perencanaan keuangan Kabupaten Sumbawa sebelum dan sesudah terbentuknya KSB dengan menggunakan beberapa rasio yaitu:

a. Rasio Efektivitas

b. Rasio Efisiensi

c. Derajat Desentralisasi

d. Rasio Ketergantungan Keuangan Daerah, dan

e. Rasio Kemandirian Keuangan Daerah.

Definisi Operasional Variabel

Realisasi perencanaan keuangan pemerintah Kabupaten Sumbawa pada dasarnya dilakuan untuk menganalisis kinerja pemerintah kabupaten di masa lalu dengan melakukan berbagai analisis sehingga diperoleh posisi keuangan yang mewakili realitas entitas dan potensi-potensi kinerja secara berkesinambungan.

(1) Rasio efektivitas keuangan pemerintah Kabupaten Sumbawa sebelum terbentuknya KSB tahun anggaran 2000-2004 adalah rasio yang digunakan untuk mengukur efektivitas dalam merealisasikan pendapatan daerah Kabupaten Sumbawa dan merupakan tingkat pencapaian pelaksanaan suatu kegiatan atau prestasi yang dicapai oleh pemerintah kabupaten yang diukur dengan membandingkan realisasi pendapatan dengan anggaran pendapatan, dalam satuan persen. Rasio efektivitas keuangan pemerintah Kabupaten Sumbawa sesudah terbentuknya KSB tahun anggaran 2000-2004 adalah rasio yang digunakan untuk mengukur efektivitas dalam merealisasikan pendapatan daerah Kabupaten Sumbawa dan merupakan tingkat pencapaian pelaksanaan suatu kegiatan atau prestasi yang dicapai oleh pemerintah kabupaten yang diukur dengan membandingkan realisasi pendapatan dengan anggaran pendapatan, dalam satuan persen. Data yang dibutuhkan dalam rasio ini adalah realisasi pendapatan dan anggaran pendapatan.

(2) Rasio efisiensi keuangan pemerintah Kabupaten Sumbawa sebelum terbentuknya KSB tahun anggaran 2000-2004 merupakan tingkat pencapaian pelaksanaan suatu kegiatan atau prestasi yang dicapai oleh pemerintah membandingkan realisasi belanja dengan realisasi pendapatan yang telah ditetapkan, dalam satuan persen. Rasio efisiensi keuangan pemerintah Kabupaten Sumbawa sesudah terbentuknya KSB tahun anggaran 2005-2010 merupakan tingkat pencapaian pelaksanaan suatu kegiatan atau prestasi yang dicapai oleh pemerintah membandingkan realisasi belanja dengan realisasi pendapatan yang telah ditetapkan, dalam satuan persen. Data yang dibutuhkan dalam rasio ini adalah realisasi belanja dan realisasi pendapatan.

(3) Derajat desentralisasi Kabupaten Sumbawa sebelum terbentuknya KSB tahun anggaran 2000-2004 merupakan perbandingan antara jumlah PAD dengan total penerimaan Kabupaten Sumbawa. Rasio ini menunjukkan derajat kontribusi PAD terhadap total pendapatan Kabupaten Sumbawa. Semakin tinggi kontribusi PAD maka semakin tinggi kemampuan pemerintah daerah dalam penyelenggaraan desentralisasi. Derajat desentralisasi Kabupaten Sumbawa sesudah terbentuknya KSB tahun anggaran 2000-2004 merupakan perbandingan antara jumlah PAD dengan total pendapatan Kabupaten Sumbawa. 
Rasio ini menunjukkan derajat kontribusi PAD terhadap total pendapatan Kabupaten Sumbawa. Semakin tinggi kontribusi PAD maka semakin tinggi kemampuan pemerintah daerah dalam penyelenggaraan desentralisasi.

(4) Rasio ketergantungan keuangan Kabupaten Sumbawa sebelum terbentuknya KSB mencerminkan ketergantungan pemerintah daerah tahun anggaran 2000-2004 terhadap pemerintah pusat yang dihitung dengan cara membandingkan antara pendapatan transfer Kabupaten Sumbawa dengan total pendapatan Kabupaten Sumbawa. Rasio ketergantungan daerah sesudah terbentuknya KSB mencerminkan ketergantungan pemerintah Kabupaten Sumbawa tahun anggaran 2005-2010 terhadap pemerintah pusat yang dihitung dengan cara membandingkan antara pendapatan transfer Kabupaten Sumbawa dengan total pendapatan Kabupaten Sumbawa.

(5) Rasio kemandirian keuangan pemerintah Kabupaten Sumbawa sebelum terbentuknya KSB menunjukkan kemampuan pemerintah kabupaten tahun anggaran 20002004 dalam membiayai sendiri kegiatan pemerintahan, pembangunan dan pelayanan kepada masyarakat yang dihitung dengan membagi total PAD Kabupaten Sumbawa dengan transfer pemerintah pusat dan provinsi Nusa Tenggara Barat dalam satuan persen. Rasio kemandirian keuangan pemerintah Kabupaten Sumbawa sesudah terbentuknya KSB menunjukkan kemampuan pemerintah kabupaten tahun anggaran 2005-2010 dalam membiayai sendiri kegiatan pemerintahan, pembangunan dan pelayanan kepada masyarakat yang dihitung dengan membagi total PAD dengan transfer pemerintah pusat dan provinsi dalam satuan persen.

Data-data yang diperlukan dalam rasio-rasio di atas adalah sebagai berikut :

(1) Realisasi pendapatan adalah segala sesuatu yang mencerminkan hasil dari segala hak pemerintah daerah Kabupaten Sumbawa yang diakui sebagai penambah nilai kekayaan bersih..

(2) Anggaran pendapatan adalah hasil yang diharapkan dari segala hak pemerintah daerah Kabupaten Sumbawa yang diakui sebagai penambah nilai kekayaan bersih.

(3) Realisasi belanja adalah segala sesuatu yang mencerminkan hasil dari kewajiban pemerintah daerah Kabupaten Sumbawa yang diakui sebagai pengurang nilai kekayaan bersih.

(4) Pendapatan Asli Daerah adalah pendapatan yang diperoleh Kabupaten Sumbawa yang dipungut berdasarkan Peraturan Daerah sesuai dengan peraturan perundang-undangan yang terdiri dari pajak, retribusi, Bagian Laba BUMD dan Lain-lain PAD yang Sah.

(5) Pendapatan Transfer adalah penerimaan/pengeluaran uang dari suatu entitas pelaporan dari/kepada entitas pelaporan lain, termasuk dana perimbangan dan dana bagi hasil.

(6) Total pendapatan adalah segala sesuatu yang mencerminkan hasil dari segala hak pemerintah daerah Kabupaten Sumbawa yang diakui sebagai penambah nilai kekayaan bersih seperti PAD, Dana Perimbangan/Pendapatan Transfer dan Pendapatan Lainnya yang Sah.
Metode Analisis Data

Uji Signifikansi (Uji t test)

Uji signifikansi hipotesis dapat dilakukan dengan uji $t$ test dimana digunakan untuk mengetahui apakah terdapat perbedaan realisasi perencanaan daerah yang diukur atas dasar Efektivitas, Efisiensi, Derajat Desentralisasi, Tingkat Ketergantungan, dan Tingkat Kemandirian Kabupaten Sumbawa sebelum (tahun 2000-2004) dan sesudah (tahun 2005-2010) terbentuknya KSB. Untuk mengujinya digunakan Uji Statistik Beda Dua Rata-Rata Pengamatan Berpasangan menurut Wirawan (2002).

Adapun langkah-langkah dalam pengujian hipotesis ini adalah sebagai berikut:

a. Merumuskan hipotesis:

Ho $:$ bi $=0 \quad$ artinya Tidak terdapat perbedaan yang signifikan realisasi perencanaan keuangan Kabupaten Sumbawa yang diukur atas dasar Efektivitas, Efisiensi, Derajat Desentralisasi, Tingkat Ketergantungan, dan Tingkat Kemandirian sebelum dan sesudah terbentuknya KSB.

Hi : bi $\neq 0 \quad$ artinya Terdapat perbedaan yang signifikanrealisasi perencanaan keuangan Kabupaten Sumbawa yang diukur atas dasar Efektivitas, Efisiensi, Derajat Desentralisasi, Tingkat Ketergantungan, dan Tingkat Kemandirian sebelum dan sesudah terbentuknya KSB.

b. Menentukan level of significant (tarif nyata), yaitu sebesar $0.05(5 \%)$

c. Menentukan statistik uji yang sesuai

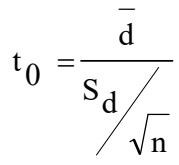

Dengan :

$\overline{\mathrm{d}}=$ nilai rata - rata beda $\mathrm{n}$ pengamatan berpasangan

$\mathrm{S}_{\mathrm{d}}=$ simpangan baku beda pengamatan berpasangan

$S_{d}=\sqrt{\frac{\sum\left(d_{1}-\bar{d}\right)^{2}}{(n-1)}}$

$\overline{\mathrm{d}}=\frac{\sum \mathrm{d}_{1}}{\mathrm{n}}$

$\mathrm{d}_{1}=$ beda pengamatan pasangan yang $\mathrm{ke}-\mathrm{i}$

$\mathrm{d}_{\mathrm{f}}=\mathrm{v}=(\mathrm{n}-1)$ 
d.

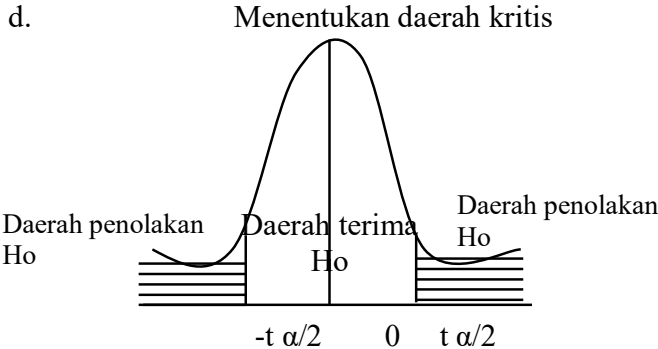

e. Menentukan nilai signifikansi dengan bantuan program SPSS.

f. Menarik kesimpulan.

Ho ditolak berarti terdapat perbedaan yang signifikan realisasi perencanaan keuangan Kabupaten Sumbawa yang diukur atas dasar Efektivitas, Efisiensi, Derajat Desentralisasi, Tingkat Ketergantungan, dan Tingkat Kemandirian sebelum dan sesudah terbentuknya KSB atau Ho diterima berarti tidak terdapat perbedaan yang signifikan realisasi perencanaan keuangan Kabupaten Sumbawa yang diukur atas dasar Efektivitas, Efisiensi, Derajat Desentralisasi, Tingkat Ketergantungan, dan Tingkat Kemandirian sebelum dan sesudah terbentuknya KSB.

\section{Hasil}

\section{Uji Beda (t-test)}

Uji hipotesis dapat dilakukan dengan uji t test dimana digunakan untuk mengetahui apakah terdapat perbedaan yang signifikan realisasi perencanaan keuangan yang diukur atas dasar Efektivitas, Efisiensi, Derajat Desentralisasi, Tingkat Ketergantungan Keuangan Daerah, dan Tingkat Kemandirian Kabupaten Sumbawa sebelum dan sesudah terbentuknya KSB, maka dilakukan pengujian dengan melakukan pengujian uji $\mathrm{t}$ test dua sampel berpasangan (Paired Sample t-test) dengan bantuan SPSS 16, yang hasilnya terdapat pada tabel di bawah ini.

Tabel 3. Hasil Analisis Uji Beda Kinerja Keuangan Kabupaten Sumbawa Sebelum dan Sesudah Terbentuknya KSB

\begin{tabular}{lccc}
\hline \multicolumn{1}{c}{ Alat Ukur } & $\begin{array}{c}\text { Nilai Sig. } \\
\text { (tailed) }\end{array}$ & $\begin{array}{c}\text { Nilai } \\
\text { tojos: }\end{array}$ & Ho \\
\hline $\begin{array}{l}\text { Efektivitas } \\
\text { Efisiensi }\end{array}$ & $-2,579$ & 2,750 & Diterima \\
$\begin{array}{l}\text { Derajat } \\
\text { Desentralisasi } \\
\text { Tingkat }\end{array}$ & 0,825 & 2,750 & Diterima \\
$\begin{array}{l}\text { Ketergantungan } \\
\text { Keuangan }\end{array}$ & $-0,439$ & 2,750 & Diterima \\
$\begin{array}{l}\text { Daerah } \\
\text { Kemandirian }\end{array}$ & 0,921 & 2,750 & Diterima \\
Daerah & & & \\
\hline Sumber : Lampiran $12-16$ & &
\end{tabular}

Dari hasil uji $\mathrm{t}$, diperoleh nilai $\mathrm{t}$ hitung efektivitas $(1,579)<\mathrm{t}$ tabel $(2,750), \mathrm{t}$ hitung efisiensi $-2,072>\mathrm{t}$ tabel $(-2,750), \mathrm{t}$ hitung derajat desentralisasi $(0,825)<\mathrm{t}$ tabel $(2,750), \mathrm{t}$ hitung tingkat ketergantungan keuangan daerah $(-0,439)>\mathrm{t}$ tabel $(-2,750)$ dan $t$ hitung kemandirian daerah $(0,921)<\mathrm{t}$ tabel
$(2,750)$. Artinya Ho diterima artinya realisasi perencanaan keuangan Kabupaten Sumbawa yang diukur atas dasar Efektivitas, Efisiensi, Derajat Desentralisasi, Tingkat Ketergantungan, dan Tingkat Kemandirian sebelum dan sesudah terbentuknya KSB tidak memiliki perbedaan yang signifikan karena t hitung lebih besar dari t tabel. Secara umum, rata-rata nilai signifikansi menunjukkan tidak ada beda yang signifikan sebelum dan sesudah terbentuknya KSB.

\section{Kesimpulan}

Berdasarkan hasil analisis yang telah diuraikan diatas, maka dapat disimpulkan bahwa tidak terdapat perbedaan yang signifikan dalam realisasi perencanaan keuangan yang diukur atas dasar Efektivitas, Efisiensi, Derajat Desentralisasi, Tingkat Ketergantungan, dan Tingkat Kemandirian Kabupaten Sumbawa sebelum dan sesudah terbentuknya KSB.

Daftar Pustaka

Amri, Isal. 2007. Pengelolaan Keuangan Daerah. Yogyakarta: UPP STIM YKPN.

Anonim. 2008. Studi Evaluasi Dampak Pemekaran Daerah 2001-2007. Jakarta: Building and Reinventing Decentralised Governance 2000. Penerimaan dan Pengeluaran Daerah Kabupaten Sumbawa Tahun 2000. Badan Pusat Statistik Kabupaten Sumbawa

, Peraturan Pemerintah Nomor 58 tahun 2005 tentang Standar Akuntansi Pemerintahan Daerah. , Peraturan Pemerintah Nomor 71 tahun 2010 tentang Standar Akuntansi Pemerintahan Daerah. , Peraturan Menteri Dalam Negeri No. 13 tahun 2006 tentang Pedoman Pengelolaan Keuangan Daerah.

, Undang-undang Nomor 32 tahun 2004 tentang Pemerintah Daerah (www.indonesia.go.id)

, Undang-Undang No. 33/2004 tentang Perimbangan Keuangan Pemerintah Pusat dan Pemerintah Daerah (www.indonesia.go.id)

Batafor, Gregorius Gehi. 2011. Evaluasi Kinerja Keuangan dan Tingkat Kesejahteraan Masyarakat Kabupaten Lembata-Provinsi NTT. Program PascaSarjana: Universitas Udayana.

Dahman. 2009. Analisis Pengelolaan dan Kemampuan Keuangan Daerah dalam Rangka Pelaksanaan Otonomi Daerah di Provinsi Nusa Tenggara Barat tahun Anggaran 2003-2007. Program PascaSarjana Magister Manajemen: Universitas Mataram.

Halim, Abdul dan Damayanti, Theresia. 2007. Pengelolaan Keuangan Daerah. Yogyakarta: UPP STIM YKPN.

Hartono. 2008. SPSS 16.0 Analisis Data Statistika dan Penelitian. Yogyakarta: Pustaka Belajar.

Idirman. 2007. Pengelolaan Keuangan Daerah. Yogyakarta: UPP STIM YKPN.

Karya Satya Azhar, Muhammad. 2008. Analisis Kinerja Keuangan Kabupaten/Kota Sebelum dan Sesudah Otonomi Daerah. Program Studi Ilmu Akuntansi: Universitas Sumatera Utara. 
Mahmudi. 2007. Analisis Laporan Keuangan Pemerintah Daerah. Yogyakarta: Sekolah Tinggi Ilmu Manajemen YKPN.

Makrifah, Siti Anni. 2010. Analisis Pengelolaan Keuangan Daerah dan Dampaknya terhadap Pembangunan Ekonomi Provinsi Jawa Timur. Sekolah PascaSarjana: Institut Pertanian Bogor.

Nurgiyantoro, Burhan, Gunawan dan Marzuki. 2004. Statistik Terapan untuk Penelitian Ilmu-Ilmu Sosial. Yogyakarta: Gajah Mada University Press.

Ronald, Andrean dan Dwi Sarmiyantiningsih. 2010. Analisis Kinerja Keuangan dan Pertumbuhan Ekonomin Sebelum dan Sesudah Diberlakukannya Otonomi Daerah di Kabupaten Kulon Progo. Jurnal Bisnis dan Ekonomi Vol. 1. Fakultas Ekonomi Universitas Janabadra. (tanggal download 7 Mei 2012)

Ruslan, Rosady. 2003. Metode Penelitian. Jakarta: PT. Raja Grafindo Persada

Sugiyono. 2007. Metode Penelitian Bisnis. Alfabeta. Bandung. Thesaurianto, Kuncoro. 2007. Analisis Pengelolaan Keuangan Daerah Terhadap Kemandirian Daerah. Program PascaSarjana Magister Manajemen: Universitas Diponegoro.

Wirawan, Nata. 2002. Statistik 2 (Statistik Inferensia). Keraras Emas, Denpasar

\section{Lampiran 1}

Tabel 1. Hasil Perhitungan Rasio Efektivitas Keuangan Pemerintah Kabupaten Sumbawa Sebelum dan Sesudah Terbentuknya KSB (dalam jutaan)

\begin{tabular}{|c|c|c|}
\hline Tahun & Rasio & Kriteria \\
\hline \multicolumn{3}{|c|}{ Sebelum Terbentuknya KSB } \\
\hline 2000 & 102,32 & Sangat Efektif \\
\hline 2001 & 107,36 & Sangat Efektif \\
\hline 2002 & 108,03 & Sangat Efektif \\
\hline 2003 & 99,51 & Efektif \\
\hline 2004 & 102,25 & Sangat Efektif \\
\hline Total & 519,47 & \\
\hline Rata-rata & 103,89 & Sangat Efektif \\
\hline \multicolumn{3}{|c|}{ Sesudah Terbentuknya KSB } \\
\hline 2005 & 98,33 & Efektif \\
\hline 2006 & 99,92 & Efektif \\
\hline 2007 & 103,16 & Sangat Efektif \\
\hline 2008 & 101,72 & Sangat Efektif \\
\hline 2009 & 102,49 & Sangat Efektif \\
\hline 2010 & 99,57 & Efektif \\
\hline Total & 605,19 & \\
\hline Rata-rata & 100,86 & Sangat Efektif \\
\hline
\end{tabular}

Sumber : Data Diolah
Lampiran 2

Tabel 2. Hasil Perhitungan Rasio Efisiensi Keuangan Pemerintah Kabupaten Sumbawa Sebelum dan Sesudah Terbentuknya KSB

\begin{tabular}{|c|c|c|}
\hline Tahun & Rasio & Kriteria \\
\hline \multicolumn{3}{|c|}{ Sebelum Terbentuknya KSB } \\
\hline 2000 & 82,28 & Cukup Efisien \\
\hline 2001 & 51,02 & Sangat Efisien \\
\hline 2002 & 54,01 & Sangat Efisien \\
\hline 2003 & 102,81 & Tidak Efisien \\
\hline 2004 & 93,34 & Kurang Efisien \\
\hline Total & 383,46 & \\
\hline Rata-rata & 76,69 & Efisien \\
\hline \multicolumn{3}{|c|}{ Sesudah Terbentuknya KSB } \\
\hline 2005 & 98,15 & Kurang Efisien \\
\hline 2006 & 96,85 & Kurang Efisien \\
\hline 2007 & 91,09 & Kurang Efisien \\
\hline 2008 & 94,52 & Kurang Efisien \\
\hline 2009 & 103,23 & Tidak Efisien \\
\hline 2010 & 100,92 & Tidak Efisien \\
\hline Total & 584,76 & \\
\hline Rata-rata & 97,46 & Kurang Efisien \\
\hline
\end{tabular}

Lampiran 3

Tabel 3. Hasil Perhitungan Derajat Desentralisasi Keuangan Pemerintah Kabupaten Sumbawa Sebelum dan Sesudah Terbentuknya KSB

\begin{tabular}{|c|c|c|}
\hline Tahun & Rasio & Kriteria \\
\hline \multicolumn{3}{|c|}{ Sebelum Terbentuknya KSB } \\
\hline 2000 & 5,13 & Sangat Kurang \\
\hline 2001 & 3,95 & Sangat Kurang \\
\hline 2002 & 7,11 & Sangat Kurang \\
\hline 2003 & 6,63 & Sangat Kurang \\
\hline 2004 & 5,76 & Sangat Kurang \\
\hline Total & 28,58 & \\
\hline Rata-rata & 5,72 & Sangat Kurang \\
\hline \multicolumn{3}{|c|}{ Sesudah Terbentuknya KSB } \\
\hline 2005 & 6,21 & Sangat Kurang \\
\hline 2006 & 5,32 & Sangat Kurang \\
\hline 2007 & 4,09 & Sangat Kurang \\
\hline 2008 & 4,54 & Sangat Kurang \\
\hline 2009 & 4,87 & Sangat Kurang \\
\hline 2010 & 5,42 & Sangat Kurang \\
\hline Total & 30,45 & \\
\hline Rata-rata & 5,08 & Sangat Kurang \\
\hline
\end{tabular}

Sumber : Data Diola 
Lampiran 4

Tabel 4. Hasil Perhitungan Tingkat Ketergantungan Keuangan Daerah Pemerintah Kabupaten Sumbawa Sebelum dan Sesudah Terbentuknya KSB

\begin{tabular}{|c|c|}
\hline Tahun & Rasio \\
\hline \multicolumn{2}{|c|}{ Sebelum Terbentuknya KSB } \\
\hline 2000 & 90,37 \\
\hline 2001 & 93,08 \\
\hline 2002 & 98,93 \\
\hline 2003 & 87,39 \\
\hline 2004 & 89,26 \\
\hline Total & 459,04 \\
\hline Rata-rata & 91,81 \\
\hline \multicolumn{2}{|c|}{ Sesudah Terbentuknya KSB } \\
\hline 2005 & 89,82 \\
\hline 2006 & 94,69 \\
\hline 2007 & 90,54 \\
\hline 2008 & 95,02 \\
\hline 2009 & 95,13 \\
\hline 2010 & 94,58 \\
\hline Total & 559,78 \\
\hline Rata-rata & 93,30 \\
\hline
\end{tabular}

Sumber : Data Diolah

Lampiran 5

Tabel 5. Hasil Perhitungan Rasio Tingkat Kemandirian Keuangan Daerah Pemerintah Kabupaten Sumbawa Sebelum dan Sesudah Terbentuknya KSB

\begin{tabular}{|c|r|r|l|}
\hline Tahun & \multicolumn{1}{|c|}{ Rasio } & \multicolumn{1}{|c|}{ Kriteria } & \multicolumn{1}{|c|}{$\begin{array}{c}\text { Pola } \\
\text { Hubungan }\end{array}$} \\
\hline \multicolumn{4}{|c|}{ Sebelum Terbentuknya KSB } \\
\hline 2000 & 5,68 & Rendah Sekali & Instruktif \\
\hline 2001 & 4,24 & Rendah Sekali & Instruktif \\
\hline 2002 & 7,19 & Rendah Sekali & Instruktif \\
\hline 2003 & 7,59 & Rendah Sekali & Instruktif \\
\hline 2004 & 6,45 & Rendah Sekali & Instruktif \\
\hline Total & 31,15 & & \\
\hline $\begin{array}{c}\text { Rata- } \\
\text { rata }\end{array}$ & 6,23 & Rendah Sekali & Instruktif \\
\hline \multicolumn{5}{|c|}{ Sesudah Terbentuknya KSB } \\
\hline 2005 & 6,91 & Rendah Sekali & Instruktif \\
\hline 2006 & 5,62 & Rendah Sekali & Instruktif \\
\hline 2007 & 4,51 & Rendah Sekali & Instruktif \\
\hline 2008 & 4,78 & Rendah Sekali & Instruktif \\
\hline 2009 & 5,12 & Rendah Sekali & Instruktif \\
\hline 2010 & 5,73 & Rendah Sekali & Instruktif \\
\hline Total & 32,68 & & \\
\hline $\begin{array}{l}\text { Rata- } \\
\text { rata }\end{array}$ & 5,45 & $\begin{array}{l}\text { Rendah } \\
\text { Sekali }\end{array}$ & Instruktif \\
\hline
\end{tabular}

Sumber : Data Diolaah 